\title{
Tahun Baru 2016, Tabel Periodik Baru
}

Oleh Gede H. Cahyana

Dosen Teknik Lingkungan Universitas Kebangsaan

Awal tahun 2016 ini, murid SMA, MA, SMK khususnya Analisis Kimia perlu memperbarui hapalan unsur-unsur di dalam Tabel Periodik. Mulai tahun 2016 ini, ada 118 unsur yang mengisi tabel tersebut, bertambah empat unsur, dari sebelumnya 114 buah. Tentu tidak mudah menghapal semua unsur tersebut "di luar kepala". Ada "jembatan keledai" (sebuah istilah keliru), yang lebih tepat adalah "cara kancil” dalam menghapal semua unsur tersebut.

Jumlah 114 unsur di dalam Tabel Periodik mulai dari unsur 1 (Hidrogen) hingga 112 (Copernicium), unsur 114 (Flerovium), dan unsur 116 (Livermorium). Kini, per 30 Desember 2015, sudah resmi diumumkan oleh International Union of Pure and Applied Chemistry (IUPAC) unsur 113, 115, 117, dan 118, Unsur 113 bernama sementara ununtrium dengan simbol Uut. Penelitinya, yaitu tim kolaborasi RIKEN di Jepang akan diberi hak untuk menamai dan menyimboli secara permanen unsur temuannya tersebut.

Adapun unsur 115, 117 (nama dan simbol sementaranya: ununpentium, Uup; ununseptium, Uus) akan diperlakukan serupa. Penemunya, yaitu kolaborasi antara Joint Institute for Nuclear Research di Dubna, Russia; Lawrence Livermore National Laboratory, California, Amerika Serikat; dan Oak Ridge National Laboratory, Tennessee, Amerika Serikat diberi hak menamai dan menyimboli unsur-unsur temuannya, Yang terakhir adalah unsur 118 (Ununoctium, Uuo), hasil riset bersama Joint Institute for Nuclear Research di Dubna, Russia dan Lawrence Livermore National Laboratory, California, Amerika Serikat. Penemunya diberi hak menamai dan menyimboli unsur temuannya.

Dari jumlah 118 tersebut, 94 unsur terdapat secara alamiah dan 24 unsur sisanya hanya ada jika disintesis di laboratorium. Dari 94 unsur alamiah itu, 84 di antaranya adalah unsur purba. Sepuluh lainnya muncul jika ada peluruhan dari unsur purba tersebut.

Dengan tambahan unsur baru, maka berubah atau bertambah juga hapalan murid yang belajar kimia di SMA, MA, SMK. Lantas, bagaimana cara menghapalnya? 


\section{Cara Menghapal}

Berikut ini adalah cara menghapal unsur-unsur di dalam Tabel Periodik, khususnya Golongan A. Yang pertama, hapalkan baris kedua: Li Be B C N O F Ne. Ini mewakili unsur: Lithium, Beryllium, Boron, Carbon, Nitrogen, Oksigen, Fluor, Neon. Cara bacanya adalah libe bece nofne. Tulislah di selembar kertas libe bece nofne dalam satu baris.

Lalu mulailah tulis unsur Golongan IA (paling kiri). Pada Golongan IA ini ada tambahan H (Hidrogen) di bagian awal golongan sehingga "cara kancil" untuk menghapalnya menjadi halinaka rebcesfer. Singkatan ini menyatakan ha $=\mathrm{H}$ (Hidrogen), li = Li (Lithium), na $=\mathrm{Na}$ (Natrium), $\mathrm{ka}=\mathrm{K}($ Kalium), $\mathrm{reb}=\mathrm{Rb}($ Rubidium $), \mathrm{ces}=\mathrm{Cs}($ Caesium $)$, fer $=$ Fr $($ Francium $)$.

Cara Kancil Golongan IIA adalah bema caser bara. Suku-kata ini menyatakan be $=\mathrm{Be}$ (Beryllium), $\mathrm{ma}=\mathrm{Mg}$ (magnesium), $\mathrm{ca}=\mathrm{Ca}($ Calcium $)$, ser $=\mathrm{Sr}($ Strontium $), \mathrm{ba}=\mathrm{Ba}$ (Barium), ra= Ra (Radium).

Golongan IIIA, cara kancilnya ialah libe be yang bagian be-nya atau B. Unsur B (Boron) ini menjadi awal hapalan: balga intalut, yang menyatakan $\mathrm{b}=\mathrm{B}$ (Boron), $\mathrm{al}=\mathrm{Al}$ (aluminum), ga $=\mathrm{Ga}($ Gallium $)$, in = In (Indium), tal = Tl (Thallium), ut = Uut (ununtrium, unsur baru).

Golongan IVA, rujuk lagi ke libe bece, yaitu ce yang sama dengan $\mathrm{C}=$ Carbon. Unsur carbon menjadi awal singkatan cesige senpeb fle yang menyatakan ce $=\mathrm{C}$ (Carbon), si $=\mathrm{Si}$ (silicon), ge $=$ Ge $($ Germanium $)$, sen $=$ Sn (Stanum, Tin), peb = Pb (Plumbum, Lead, timbal), fle $=$ Fl (Flerovium)

Golongan VA, kembali lihat libe bece nofne. Unsur kuncinya adalah $\mathrm{n}$ atau N (Nitrogen). Maka golongan VA ini dimulai dari $\mathrm{N}$ dengan singkatan cara kancilnya: enpas esbe biup. Artinya: en $=\mathrm{N}$ (Nitrogen), $\mathrm{p}=\mathrm{P}$ (Phosphate), as = As (Arsenic), $\mathrm{sb}=\mathrm{Sb}$ (Antimony), $\mathrm{bi}=$ Bi (Bismuth), up = Uup (ununpentium, unsur baru).

Golongan VIA, kembali ke libe bece nofne, diperoleh o atau O (Oksigen) sehingga diperoleh cara kancil golongan ini adalah osse tepoliv. Huruf o $=\mathrm{O}($ Oksigen$), \mathrm{s}=\mathrm{S}$ (Sulfur), $\mathrm{se}=\mathrm{Se}$ $($ Selenium $)$, te $=$ Te $($ Tellurium $)$, po $=$ Po $($ Polonium $)$, liv $=\mathrm{Lv}($ livermorium $)$. 
Golongan VIIA, kembali ke libe bece nofne, diperoleh huruf $f$ atau F (fluor). Singkatan untuk golongan VIIA ini menjadi efklor briatus. Huruf ef $=\mathrm{F}$ (Fluorine), klor $=\mathrm{Cl}$ (chlorine), br $=$ $\mathrm{Br}=$ Bromine, $\mathrm{I}=\mathrm{I}$ (Iodine), at= At (Astatine), us = Uus (ununseptium, unsur baru).

Yang terakhir adalah Golongan VIIIA atau gas mulia. Lihat lagi libe bece nofne. Diperoleh ne untuk Ne (Neon). Seperti halnya Golongan IA, Golongan VIIIA ini pun memiliki unsur awal, yaitu He (Helium). Cara kancil golongan ini menjadi henear krikserenuo. Huruf he = He $($ Helium $), n e=\mathrm{Ne}($ Neon$), \operatorname{ar}=\operatorname{Ar}($ Argon $)$, krik $=$ Kr $($ Krypton $), k s e=$ Xe $($ Xenon $)$, dan $\mathrm{rn}=\mathrm{Rn}($ Radon $)$, uo = Uuo (Ununoctium, unsur baru).

Tentu saja, unsur-unsur baru bisa saja ditemukan lagi pada masa yang akan datang sehingga dapat mengubah sebagian atau seluruh susunan sel di dalam Tabel Periodik. Sebagai contoh, Golongan IVA dan VIA baris tujuh belum ada pada dekade 1980-an, yaitu unsur 114 dan 116. Bahkan pada dekade sebelumnya, hanya ada tiga unsur saja di periode tujuh, yaitu $\mathrm{Fr}$, $\mathrm{Ra}$, dan $\operatorname{Lr}$ (lawrencium). Akhirnya ditemukan juga unsur-unsur lainnya yaitu $U n q=R f=$ Rutherfordium, $U n p=D b=$ Dubnium, Unh $=S g=$ Siborgium, Uns $=$ Bh $=$ Bohrium, Uno $=$ $H s=$ Hasium, Une $=M t=$ Meitnerium, Uun $=D s=$ Darmstadtium, Uuu $=R g=$ Roentgenium, $U u b=C n=$ Copernicium, $U u q=F l=$ flerovium, Uup, $U u h=L v=$ Livermorium. Uus, Uuo. Adapun Uut, Uup, Uus, dan Uuo sudah dipastikan unsur baru dan akan dibuatkan nama dan simbolnya. Dengan demikian, mulai awal tahun baru 2016 ini penuh sudah periode tujuh dengan 18 unsur-unsurnya.

Tentu saja hapalan yang final bisa dibuat setelah nama dan simbol resmi empat unsur baru tersebut sudah ditetapkan. Namun untuk sementara, nama dan simbol seperti dibahas di atas bisa dihapalkan sebagai tambahan pengetahuan di dalam rumpun ilmu kimia.* 